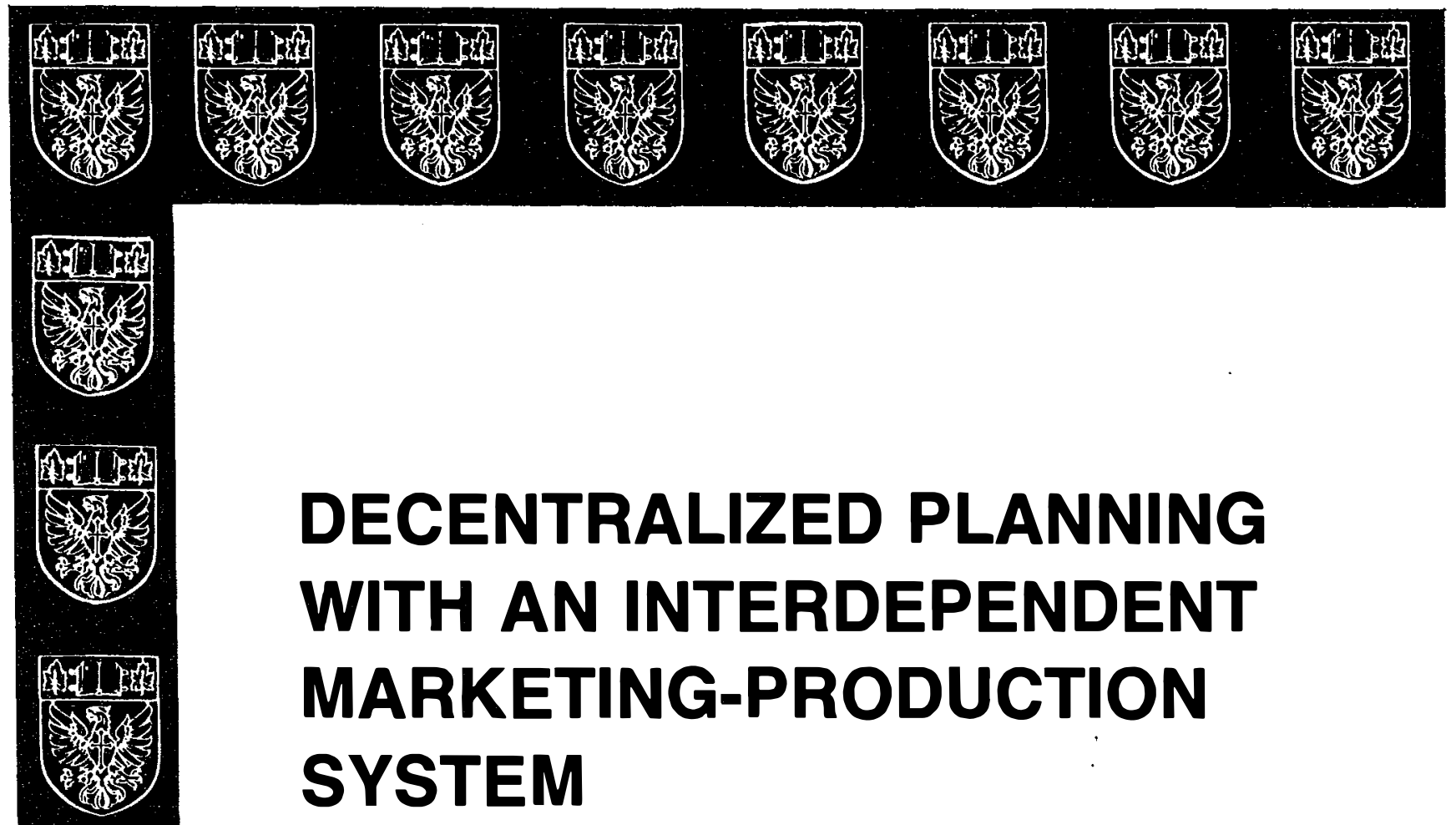

Prakash L. Abad

McMaster University

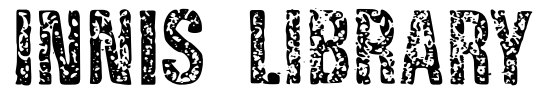

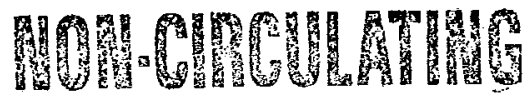

FACULTY OF BUSINESS

McMASTER UNIVERSITY

HAMILTON, ONTARIO 
Abstract

An interdependent marketing-production planning model is developed based on control theory. The overall model is a composition of the Vidale-Wolfe model relating advertising rates to sales rates, and the HMMS production/ inventory planning model. Using the overall model as a reference point, it is shown that in certain circumstances a deçentralized (separate) marketingproduction planning process can yield near optimal results. A transfer pricing mechanism provides the best results and several examples are presented to illustrate the cases in which decentralized planning does and does not work we11. 


\section{DECENTRALIZED PLANNING WITH AN \\ INTERDEPENDENT MARKETING-PRODUCTION SYSTEM}

\section{INTRODUCTION}

A1though the marketing and production functions in a firm are normally organized separately, the two functions are not independent. The relationship between the two functions is embodied in the firm's demand. Marketing policies such as pricing and promotion are designed to generate demand for the firm's products, whereas production policies, such as establishing production rates and maintaining in process and finished goods impentories, are designed to meet that demand.

The interdependencies between the two functions become further evident when one analyzes the costs involved in generating and meeting demand. In the first place, revenue can only be realized if the demand generated by marketing policies is met by past, current, or future production. Unmet demand does not result in revenue; it only results in marketing costs. Secondly, for a firm with a fixed capacity, the unit cost of production is generally a U-shaped function of its production rate. Thus, given that a firm sets its marketing policies to generate demand and its production rates to meet that demand, it becomes apparent that the firm's production rates and hence its unit cost of production are indirectly influenced by its marketing policies.

If marketing and production policies are really interdependent, then a case can obviously be made for simultaneous planning. The problem of simultaneous planning of marketing-production policies has been the subject matter of several previous papers $[4,6,12,15,23,24,25]$. In this paper, a 
new interdependent model of a marketing-production system is proposed. The proposed model is based upon the Vidale-Wolfe model of advertising [26] and the HMMS model of production planning $[9,10]$. Using the proposed model as a description of the firm's ideal organization problem, ${ }^{1}$ a decentralized procedure for separate planning of the firm's advertising and production policies is designed. We show that in some situations, the separate (decentralized) approach, which takes into consideration the constraints imposed by the organization structure, renders solutions that are as good as the solutions rendered by the interdependent approach. In other cases we show that decentralized planning can lead to significant suboptimality. Six examples are given to illustrate conditions in which decentralized planning does and does not work well.

2. AN INTERDEPENDENT MODEL FOR MARKETING-PRODUCTION PLANNING

As stated earlier, the interdependent model of a marketingproduction system proposed in this paper is based upon the Vidale-Wolfe advertising model [26] and the HMMS model of production planning [9]. The model proposed makes use of the following variable definitions: $\underline{\text { Variables }}$

$$
\begin{aligned}
S(t)= & \text { Sales rate at time }(t) \quad(\$ / \text { day). } \\
I(t)= & \text { Level of inventory at time }(t) \text { (Units). } \\
P(t)= & \text { Rate of production at time }(t) \text { (Units/day). } \\
A(t)= & \text { Rate of advertising expenditure } \\
& \text { at time }(t) \text { (\$ay). }
\end{aligned}
$$


Relationship Between the Sales Rate $S(t)$ and the Rate of Advertising Expenditure $A(t)$

The relationship between the sales rate and rate of advertising expenditure is modeled using the Vidale-Wolfe model [26] .

$$
\dot{S}(t)=\frac{d S(t)}{d t}=r A(t)[1-S(t) / M]-\lambda S(t)
$$

where

$$
\begin{aligned}
\dot{S}(t) & =\frac{d S(t)}{d t}=\underset{\text { rate of change of } S(t) \text { at time } t}{\left(\$ / d a y^{2}\right)} \\
\lambda & =\text { sales decay constant } \\
r & =\text { sales response constant } \\
M & =\text { saturation level of sales rate }(\$ / \text { day }) .
\end{aligned}
$$

The Vidale-Wolfe model was selected to represent the sales-advertising relationship because:

1. The model has been empirically validated; see [26]

2. Compared to the Koyck-type distributed lag model [13], which has been used in previous formulations of the interdependent models of marketing-production systems $[6,15]$, the Vidale-Wolfe model has the following desirable properties:

a) The saturation level of the sales rate in the Vidale-Wolfe model is finite.

b) The advertising effectiveness is a decreasing function of the accumulated goodwill (i.e. goodwill to date) rather than just the goodwill generated in the current period [2].

3. The Vidale-Wolfe model has been used to derive the optimal advertising policies for the marketing subsystem $[18,19,21]$. 
Relationship Among the Level of Inventory, Production Rate and the Sales Rate

The relationships among the level of inventory $I(t)$, the production rate $P(t)$, and the sales rate $S(t)$ can be described by the following identity,

$$
\dot{I}(t)=\frac{d I(t)}{d t}=P(t)-S(t) / C
$$

where

$$
\begin{aligned}
& \dot{I}(t)=d I(t) / d t=\text { rate of change of } I(t) \text { at } \\
& \text { time } t \text { (Units/day). } \\
& C=\text { The unit selling price, which is assumed to be constant. } \\
& \text { Note that the dimensions of } I(t) \text { and } P(t) \text { are units and units/day }
\end{aligned}
$$

whereas the dimensions of $S(t)$ are (\$/day). Thus division of $S(t)$ by unit selling price (C) is necessary to ensure consistent dimensions in the above identity.

Objective Function

To incorporate the interdependencies between the marketing and production costs in the firm, a total cost approach is adopted. The rate of total production cost is assumed to be [9].

$$
C_{v} P(t)+C_{p}\left[P(t)-P^{*}(t)\right]^{2}
$$

where ${ }^{2}$

$$
\begin{aligned}
& \mathrm{C}_{\mathrm{v}}=\text { Per unit cost of raw material, direct labor and other production } \\
& \text { costs that are proportional to } \mathrm{P}(\mathrm{t}) \text {. } \\
& C_{p}\left[P(t)-P^{*}(t)\right]^{2}=\text { The rate of costs that are related to the } \\
& \text { deviation of the actual rate of production, } P(t) \text {, } \\
& \text { from the desired rate of production, } P^{*}(t) \\
& \text { (e.g. undertime-overtime costs). }
\end{aligned}
$$


The rate of total inventory costs is assumed to be

$$
f_{I}(t)+C_{I}\left[I(t)-I^{*}(t)\right]^{2}
$$

where

$$
\begin{aligned}
& f_{I}(t)=\text { Base inventory cost (rate) } \\
& C_{I}\left[I(t)-I^{*}(t)\right]^{2}= \begin{array}{l}
\text { Rate of costs associated with the deviation of } \\
\text { the actual level of inventory, } I(t), \text { from the } \\
\text { desired level of inventory } I^{*}(t) .
\end{array}
\end{aligned}
$$

The rate of advertising cost is simply $A(t)$ whereas the rate of all other variable selling and administrative costs is assumed to be $q S(t)$, where $\mathrm{q}$ is a fraction between 0 and 1. The objective is assumed to be one of maximization of profit during the planning period plus the value of the inventory and goodwill at the end of the planning period. Thus the objective function is formulated as:

$$
\begin{aligned}
& \mathrm{J}(\mathrm{A}, \mathrm{P})=\text { total revenue }- \text { total advertising costs - total production } \\
& \text { costs - total inventory costs - total all } \\
& \text { other variable costs - total all other fixed } \\
& \text { costs + the value } e^{-1} \text { the inventory at the } \\
& \text { end of the planning period + the value of the } \\
& \text { goodwill at the end of the planning period. } \\
& =\int_{0}^{T} S(t) d t-\int_{0}^{T} A(t) d t \\
& -\int_{0}^{T}\left[C_{v} P(t)+C_{p}\left(P(t)-P^{*}(t)\right)^{2}\right] d t \\
& -\int_{0}^{T}\left[C_{I}\left(I(t)-I^{*}(t)\right)^{2}+f_{I}(t)\right] d t \\
& -\int_{0}^{T} q S(t) d t-F_{a}+b_{1} I(t)+b_{2} S(t)
\end{aligned}
$$


where

$$
\begin{aligned}
& \mathrm{b}_{1}=\text { value of a unit of inventory at } \mathrm{t}=\mathrm{T} \\
& \mathrm{b}_{2}=\text { value of goodwill represented by a unit sales rate at } t=\mathrm{T} \\
& \mathrm{F}_{\mathrm{a}}=\text { total all other fixed costs }
\end{aligned}
$$

The Overall Model

Collecting terms in the objective function shown in equation (5) and adding constraints the overall model is now formulated (the time arguments have been suppressed for notational. simplicity) in. a minimization format:

$$
\begin{aligned}
\min -J(A, P)= & \int_{0}^{T}\left[-(1-q) S+A+C_{v} P+C_{p}\left(P-P^{*}\right)^{2}\right. \\
& \left.+C_{I}\left(I-I^{*}\right)^{2}\right] d t-b_{1} I(T)-b_{2} S(T)+F \\
\text { s.t. } \quad \dot{I}=P & -S / C
\end{aligned}
$$

(SP)

$$
\dot{S}=\operatorname{rA}(1-S / M)-\lambda S
$$

$$
\begin{aligned}
& A_{\min } \leq A \leq A_{\max } \\
& I(0)=I_{0}, S(0)=S_{0}
\end{aligned}
$$

where

$F=\int_{0}^{T} f_{I} d t+F_{a}=$ total fixed costs

$I_{0}=$ initial level of inventory

$\mathrm{S}_{0}=$ initial sales rate.

$\mathrm{A}_{\max }=$ maximm rate of advertising that the firm can effectively maintain $\begin{aligned} A_{\text {min }}= & \text { minimum rate of advertising that the firm can effectively maintain } \\ & \text { (assumed to be } 0 \text { in this paper). }\end{aligned}$ 
Note that the above formulation does not include the constraints $I(t) \geq 0$ and $P(t) \geq 0$ (i.e. constraints reflecting no back-ordering) because it is assumed that the presence of the quadratic penalties in the objective function rules out the possibility of $\mathrm{I}(\mathrm{t})<0$ or $\mathrm{P}(\mathrm{t})<0$. Also, for simplicity, $\mathrm{P}^{*}$ and $\mathrm{I}^{*}$ are assumed to be constant with respect to time.

\section{AN EXAMPLE OF THE INTERDEPENDENT POLICY}

The single product model (SP) described in the previous section involves two dependent variables $[S(t)$ and $I(t)]$, and two control variables $[P(t)$ and $A(t)]$. Furthermore, the optimal control problem underlying the above model is "partially singular". 3

The solution procedure for the optimal control problem underlying the single product model (SP) is described in [2]. The optimal steady state solution to the above problem is characterized by equations (6) to (9). The optimal steady state sales rate, $s^{*}$, is the solution of

$$
\mathrm{P}^{*}+\frac{\mathrm{C}}{2 \mathrm{C}_{\mathrm{p}}}\left[\mathrm{q}_{\mathrm{v}}-\frac{\lambda / \mathrm{r}}{(1-\mathrm{S} / \mathrm{M})^{2}}\right]-\frac{\mathrm{S}}{\mathrm{C}}=0
$$

where $^{4}$

$$
\mathrm{q}_{\mathrm{v}}=1-\mathrm{q}-\mathrm{C}_{\mathrm{v}} / \mathrm{C} \text {. }
$$

The optimal steady state inventory level is given by

$$
I=I^{*}
$$

where $I^{*}$ is the firm's optimal level of inventory.

At steady state, $\dot{S}=0$ and $\dot{I}=0$. Thus from equations (1) and (2),

$$
A=\lambda S^{*} /\left[r\left(1-S^{*} / M\right)\right]
$$

and

$$
\mathrm{P}=\mathrm{S}^{*} / \mathrm{C}
$$


As an illustration of the interdependent approach, the following example from [2] is presented below:

Example

$$
\begin{array}{rlrl}
\mathrm{T} & =180 \text { days } & \mathrm{P}^{*}=1500 \text { units } \\
\mathrm{C}_{\mathrm{p}}=.01 & \mathrm{I}^{*}=15000 \text { units } \\
\mathrm{C}_{\mathrm{I}}=.00005 & \mathrm{C}=\$ 40 / \text { unit } \\
\lambda=.016 & \mathrm{M}=\$ 100000 / \text { day } \\
\mathrm{r}=.1 & \mathrm{I}_{0}=2000 \text { units } \\
\mathrm{q}=.1 & \mathrm{~S}_{0}=\$ 45000 / \text { day } \\
\mathrm{C}_{\mathrm{v}}=20 & \mathrm{~b}_{1}=15, \mathrm{~b}_{2}=6 \\
\mathrm{q}_{\mathrm{v}}=(1-\mathrm{q})-\mathrm{C}_{\mathrm{V}} / \mathrm{C} & \mathrm{A}_{\max }=\$ 20000 / \text { day } \\
& =(1-.1)-20 / 40 & \mathrm{~A}_{\min }=\$ 0 / \text { day }
\end{array}
$$

In this example, the optimal steady state solution yields

$$
\begin{aligned}
& S^{*}=46790.4 \quad \$ / \text { day, and } \\
& I^{*}=15000 \text { units. }
\end{aligned}
$$

The state trajectory for $S$ and $I$ in the optimal solution is shown in Figure 1. Similarly time plots of S, I, P and A are exhibited in Figure 2. From the figures, it is obvious that in this case the optimal dynamic solution is highly influenced by the optimal steady state solution $\left(S^{*}, I^{*}\right)$ as described above. During most of the planning period $S$ is near $S^{*}$ and $I$ is near $I^{*}$.

$$
\text { 4. DECENTRALIZED MARKETING-PRODUCTION PLANNING }
$$

In the previous two sections, an interdependent model for marketingproduction planning was developed and the solution for an example was illustrated. That approach assumes that a firm can plan its advertising and production policies simultaneously. 


$$
\begin{aligned}
& s^{*}=46790.4 \quad \$ / \text { day } \\
& I^{*}=15000 \text { units }
\end{aligned}
$$

58790

$-54790$

$\left(1,0, s_{0}\right)$

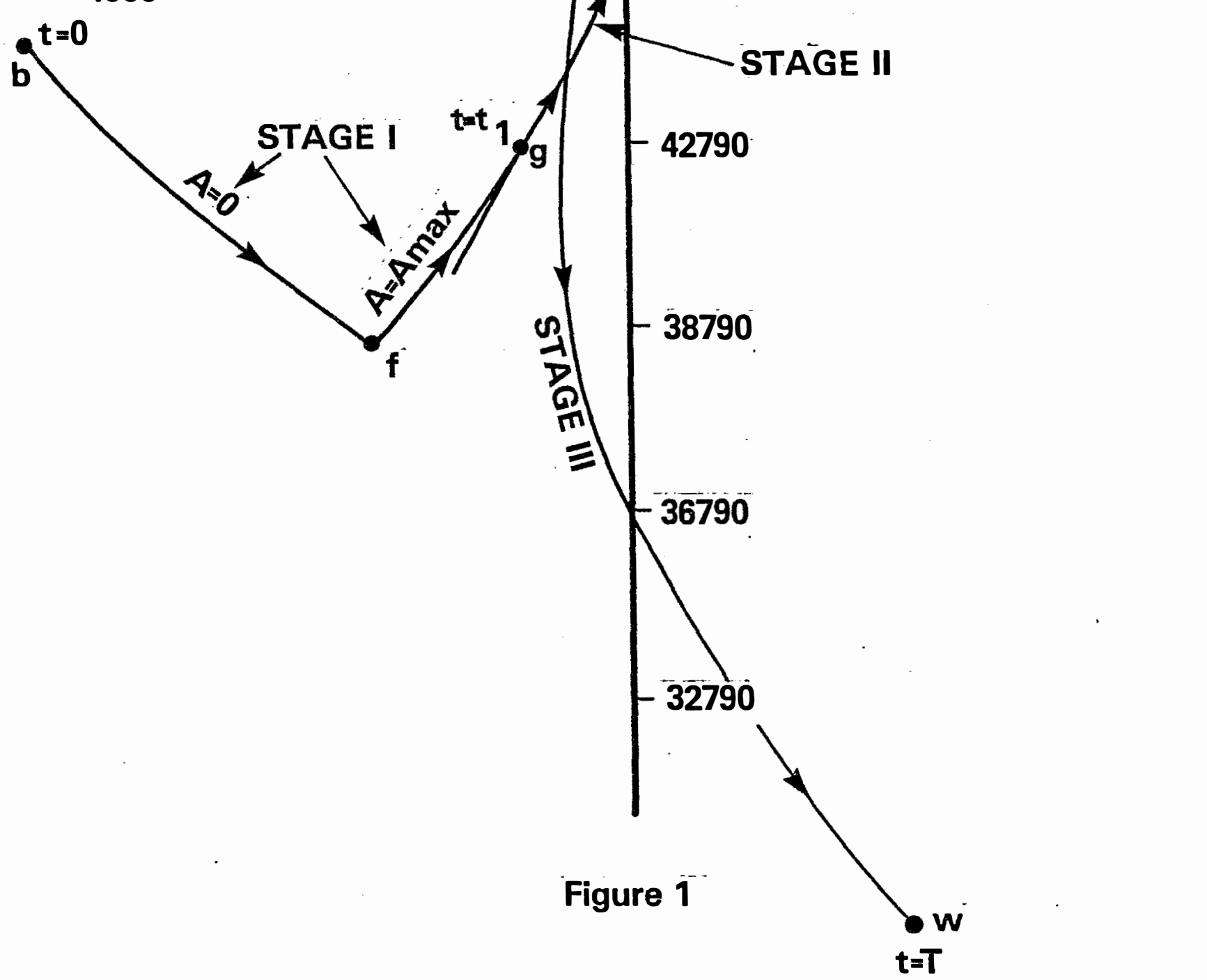



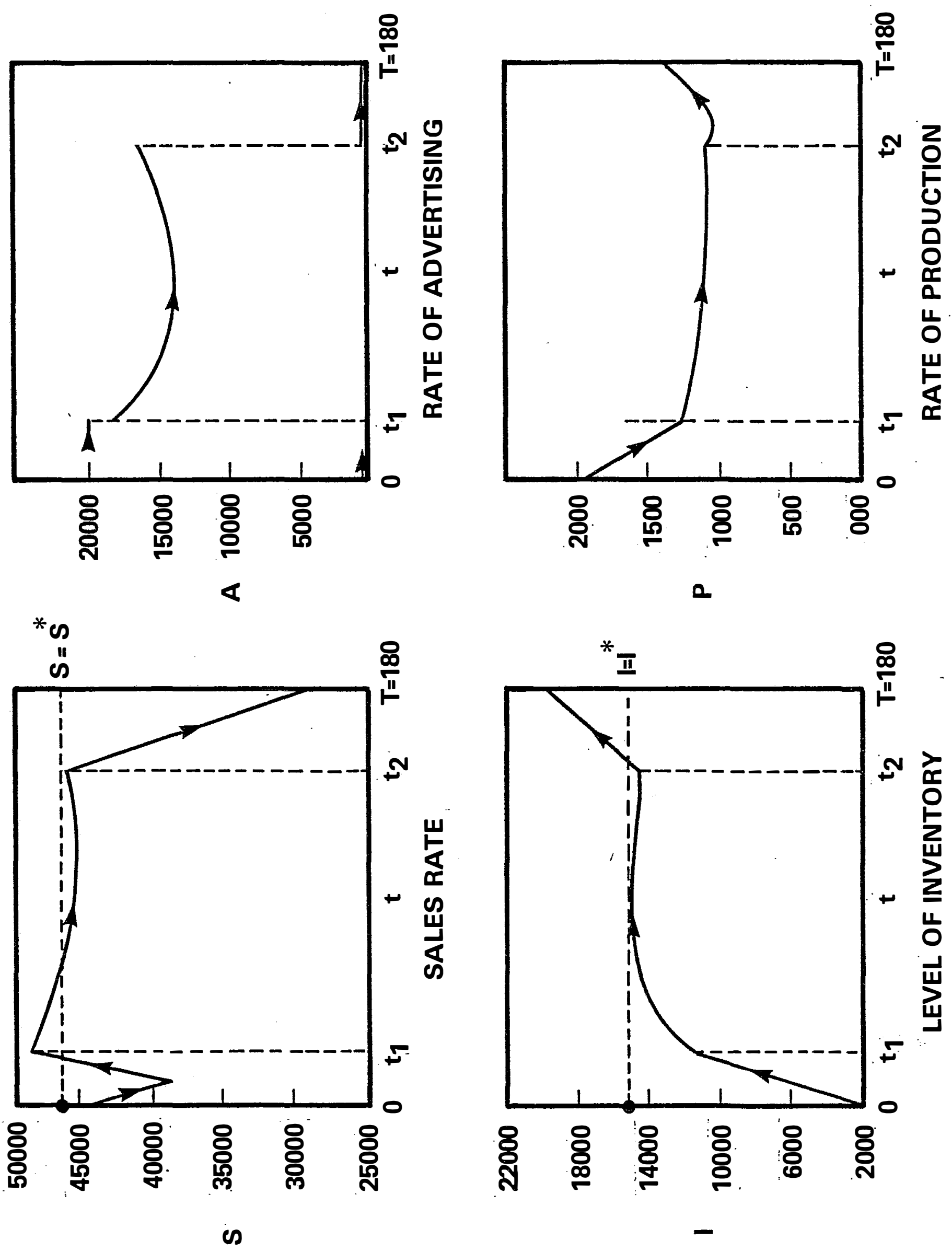
In reality however, because of the restrictions imposed by the organization structure, simultaneous planning of advertising and production policies is often not feasible. In such situations, firms employ a decentralized approach to planning.

This section is devoted to the discussion of the decentralized approach. It is assumed that the firm's ideal organization problem (i.e. the one the firm would like to solve, if possible) is the one described by the interdependent model described in the previous section, but that the firm's decision process requires that the marketing and production policies be planned separately.

In the context of the interdependent model described in the previous section, the marketing and production subproblems can be assuned to take the following form.

$$
\begin{array}{ll}
\operatorname{Min} & s^{T}\left(-q_{a} S+A\right) d t-b_{2} S(T) \\
\text { s.t. } & \dot{S}=r A[1-S / M]-\lambda S \\
& s(0)=S_{0} \\
& 0 \leq A \leq A_{\operatorname{MAX}}
\end{array}
$$

(MARK)

and

(PROD)

$$
\begin{aligned}
\operatorname{Min} & \int_{0}^{T}\left\{C_{I}\left(I-I^{*}\right)^{2}+C_{p}\left(P-\dot{P}^{*}\right)^{2}\right\} d t \\
\text { s.t. } & \dot{I}=P-S / C \\
& I(0)=I_{0} \\
& I, P \geq 0 \text { for } t \varepsilon[0, T] .
\end{aligned}
$$

In problem (PROD), $S(t)$ for $t \varepsilon[0, T]$ is assumed to be known; i.e. it is assumed that problem (MARK) is solved before problem (PROD). Also, $\mathrm{q}_{\mathrm{a}}$ in problem (MARK) is defined to be the adjusted profit margin for the marketing department 
$\left(\mathrm{q}_{\mathrm{a}}\right)$ includes production costs and it is assumed to be constant with respect to time. In order to solve problem (MARK) before problem (PROD), the decision maker must somehow specify the level for $q_{a}$.

The problem of selecting a proper level for $q_{a}$ is the key to successful implementation of the decentralized approach. We suggest a procedure for selecting the proper level for $\mathrm{q}_{\mathrm{a}}$ in a subsequent sub-section. The next sub-section however, is devoted to exanining the relationship between the optimal policy for the overall system and the suboptimal policies within the marketing and production subsystems.

Relationship Between the Optimal Policy for the Overall System and the Suboptimal Policies within the Marketing and the Production Subsystems.

It can be shown [21] that the optimal steady state (i.e. long run) solution to problem (MARK) is characterized by

$$
\begin{aligned}
& S_{S}=M\left(1-\sqrt{\lambda / r q_{a}}\right) \\
& A_{S}=M\left(\sqrt{q_{a}^{\lambda / r}}-\lambda / r\right)
\end{aligned}
$$

When

$$
\mathrm{q}_{\mathrm{a}}=\mathrm{q}_{\mathrm{v}}=1-\mathrm{q}-\mathrm{C}_{\mathrm{v}} / \mathrm{C},
$$

only the variable per unit production costs are passed to the marketing department. We then have

$$
\begin{aligned}
& \mathrm{s}_{\mathrm{s}}=\mathrm{M}(1-\sqrt{\lambda / \mathrm{rq}} \mathrm{v}) \\
& \mathrm{A}_{\mathbf{s}}=\mathrm{M}\left(\sqrt{\mathrm{q}_{\mathrm{v}} \lambda / \mathrm{r}}-\lambda / \mathrm{r}\right)
\end{aligned}
$$

The values of $\mathrm{q}_{\mathrm{a}}$ described in expression (12) ignores the quadratic production costs in the firm. As a result, the optimal steady state policy described by 
equations (13) and (14) ignores the quadratic production costs for the firm. Hence (13) and (14) can be viewed as the long run optimum within the marketing subsystem (i.e. optimm when only the marketing subsystem is considered). Also, from the model (PROD), the long run production subsystem optimm (i.e. optimun when only the production subsystem is considered) is seen to be

$$
\begin{aligned}
& P=P^{*} \\
& I=I^{*}
\end{aligned}
$$

As stated before, the long run optimum for the overall (interdependent) system is as described in equations (6) - (9). Thus, given that equations (6) (9) describe the optimal steady state solution for the overall system, they can be thought of as delineating a compromise between the marketing subsystem optimum and the production subsystem optimm. Specifically, the optimal steady state sales rate $S^{*}$ [which is the solution of equation (6)] can be viewed as a compromise solution between the marketing subsystem optimum, $M\left(1-\sqrt{\lambda / \mathrm{rq}_{\mathrm{v}}}\right)$, described in equation (13), and the sales value, $\mathrm{CP}^{*}$, of the production subsystem optimum given in equation (15) . Selecting a Proper Level for $\mathrm{q}_{\mathrm{a}}$

The level of $\mathrm{q}_{\mathrm{a}}$ should, in general, depend upon the type of co-ordination between the marketing and production department. For example, as stated earlier, if only the variable per unit production costs are passed to the marketing department, then

$$
\mathrm{q}_{\mathrm{a}}=\mathrm{q}_{\mathrm{v}}=1-\mathrm{q}-\mathrm{C}_{\mathrm{v}} \mathrm{C}
$$

On the other hand, if the firm wishes to include the costs represented by the quadratic penalty $C_{p}\left(P-P^{*}\right)^{2}$, then $q_{a}$ can be calculated as 


$$
\mathrm{q}_{\mathrm{a}}=(1-\mathrm{q})-\mathrm{C}_{\mathrm{v}} / \mathrm{C}-\underset{\text { Marginal production cost of the costs represented }}{\text { by the quadratic penalty } C_{\mathrm{p}}\left(\mathrm{P}-\mathrm{P}^{*}\right)^{2}} \text {. }
$$

or

$$
\mathrm{q}_{\mathrm{a}}=(1-\mathrm{q})-\mathrm{C}_{\mathrm{v}} / \mathrm{C}-2 \mathrm{C}_{\mathrm{p}}\left(\mathrm{P}-\mathrm{P}^{*}\right) / \mathrm{C}
$$

Equation (17) suggests that $\mathrm{q}_{\mathrm{a}}$ (the adjusted profit margin) is dependent upon the rate of production $P$. Thus in order to determine the level of $q_{a}$, the firm's management needs to estimate the level of P.

One possible approach for selecting a proper level for $\mathrm{P}$ is as follows. It can be shown that when $\mathrm{P}=\frac{\mathrm{S}^{*}}{\mathrm{C}}$; i.e. when the $\mathrm{P}$ is equal to the optimal steady state production rate in the interdependent model, the resulting $\mathrm{S}_{\mathrm{S}}$ in equation (10) is equal to $S^{*}$. That is, when $q_{a}$ is calculated using the expression

$$
\mathrm{q}_{\mathrm{a}}=\mathrm{q}_{\mathrm{a}}^{*}=(1-\mathrm{q})-\mathrm{C}_{\mathrm{v}} / \mathrm{C}-2 \mathrm{C}_{\mathrm{p}}\left(\mathrm{S}^{*} / \mathrm{C}-\mathrm{P}^{*}\right) / \mathrm{C}
$$

the optimal steady state sales rate from problem (MARK) is equal to the optimal steady state sales rate from the interdependent approach.

Thus, given the above observation, the following two-step procecume can be used to select a proper level for $\mathrm{q}_{\mathrm{a}}$ :

1. Solve for $S^{*}$ using equation (6), and

2. Using $S^{*}$, calculate $q_{a}^{*}$ using equation (18).

5. INTERDEPENDENT vs. DECENTRALIZED APPROACH: COMPUTATIONAL EVIDENCE

In this section, computational evidence from six different examples of marketing-production planning is presented. In each example, the solution rendered by the interdependent approach is compared with the solutions rendered by the decentralized approach for five different levels of $q_{a}$. The result of the comparison are presented in Table $1 .\left(\hat{a}_{a}\right)$ represents the best level of $q_{a}$ 


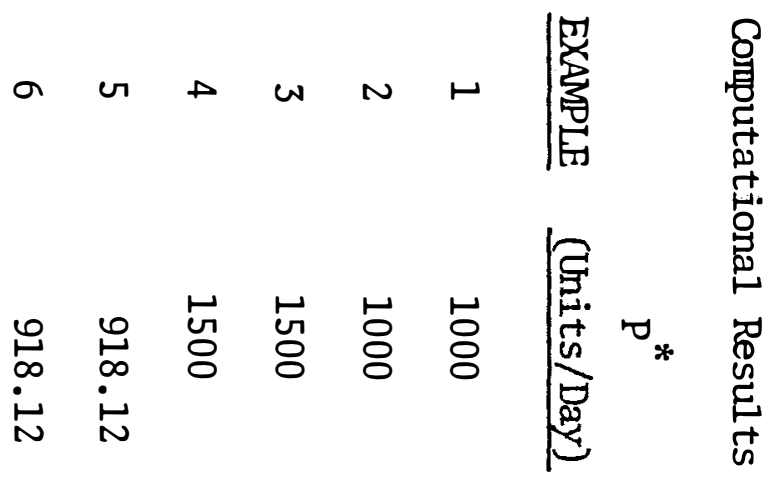

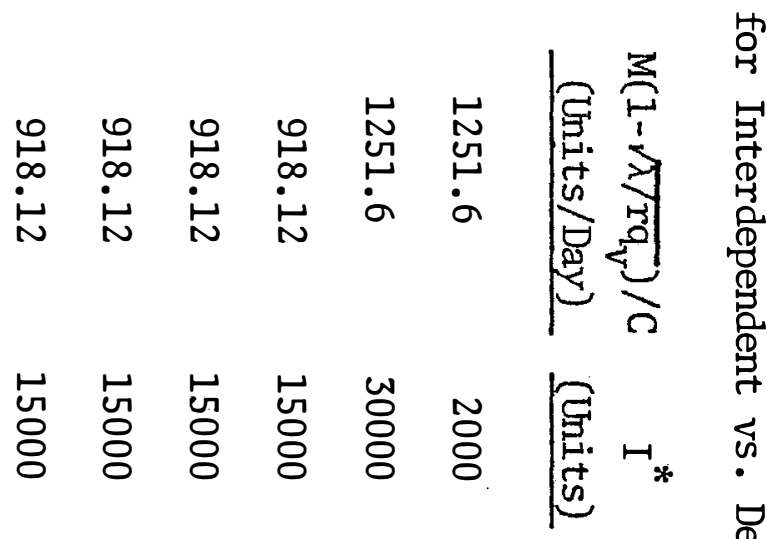

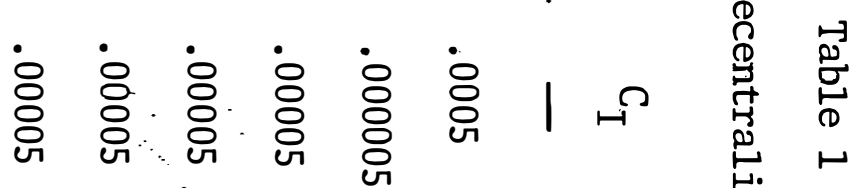

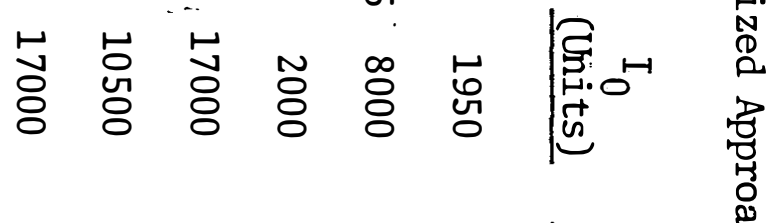
㟧

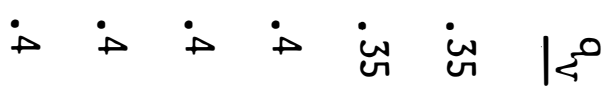

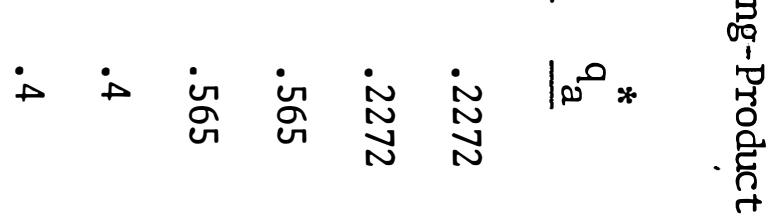
$\therefore$ in in $\underset{N}{N}$ N • 
among the five levels selected [one of them being $\mathrm{q}_{\mathrm{a}}^{*}$ - the level provided by equation (18)]. $O \mathrm{OB}^{*}$ represents the total profit from the interdependent approach whereas ${ }^{5}$ OB represents the total profit obtained using the decentralized approach with $q_{a}=\hat{q}_{a} \cdot M\left(1-\sqrt{\lambda / r q_{v}}\right) / C$ represents the marketing subsystem optimum when expressed in units of units/day and $\mathrm{P}^{*}$ represents the firm's production system capacity. Finally note that the example presented in the previous section is example 3 in the above table, and $\mathrm{S}_{0} / \mathrm{C}$ represents initial sales in units of units/day. Summary of Computation Evidence Presented in Table 1

1. In all the examples except in example 2, the difference between the solution obtained using the decentralized approach and the solution obtained using the centralized approach is small. Furthermore, in all the examples, $\hat{q}_{a}=q_{a}^{*}$. Thus the evidence presented in Table 1 strongly supports the procedure reconmended in the previous section for selecting a proper level for $\mathrm{q}_{\mathrm{a}}$.

2. In examples 5 and $6, \mathrm{P}^{*}=\mathrm{M}(1-\sqrt{\lambda / \mathrm{rq}} \mathrm{v}) / \mathrm{C}$; i.e. the firm's production subsystem optimun is equal to its marketing subsystem optimm. Or, the interdependencies between the two functions are minimal. Thus it is not surprising to see that, in these examples, the difference between the solution rendered by the interdependent approach and the solution rendered by the best decentralized approach is quite negligible.

3. In examples 1,3 and 4 , there is a significant difference between the firm's capacity (assuming $\mathrm{P}^{*}$ is a good surrogate for capacity) and the firm's marketing subsystem optimum. However, with a proper selection of $\mathrm{q}_{\mathrm{a}}$, the firm's adjusted profit margin, the decentralized approach has yielded a solution that is fairly close to the solution rendered by the interdependent approach. 
4. In example 2, the difference between the firm's capacity and the firm's marketing subsystem optimum is significant. In addition, $I^{*}$ and the difference $\left(I^{*}-I_{0}\right)$ are fairly large; i.e. the firm's variable inventory costs are significant as compared to the firm's variable production and marketing costs. Thus, in this example, the differences between the solutions rendered by the interdependent approach and the solution rendered by the best decentralized approach is quite significant. Organizational Design Implications of the Computational Evidence Exhibited in Table 1

The last three observations in the previous sub-section have obvious organization design implications. They are:

a) If the marketing and production subsystems in the firm match each other; i.e. if the marketing subsystem optimum for the firm is equal to the firm's production capacity (assuming the capacity is approximately $\mathrm{P}^{*}$ ), there is no need for any formal co-ordination between the firm's advertising and production decisions. That is, the firm can plan its advertising decisions first and then, using the demand specified by its advertising plan, plan its production decisions later.

b) If the marketing subsystem optimm and the firm's existing capacity differ significantly, then there is a critical need for formal co-ordination between the two decision areas. The co-ordination can be of two types: 
I. When the variable inventory costs are not as significant as marketing or production costs, the co-ordination can be in the form of transfer pricing. The marketing department can adjust its profit margin using the expression

$$
\mathrm{q}_{\mathrm{a}}=\mathrm{q}_{\mathrm{a}}^{*}=(1-\mathrm{q})-\mathrm{C}_{\mathrm{v}} / \mathrm{C}-2 \mathrm{C}_{\mathrm{p}}\left(\mathrm{S}^{*} / \mathrm{C}-\mathrm{P}^{*}\right) / \mathrm{C}
$$

where $S^{*}$ is the optimal steady state sales level. Thus, in this case, the firm can use the decentralized or the separate approach of planning to plan its advertising and production policies.

II. When the variable inventory costs are as significant as the marketing and production costs, the firm is better off planning its advertising and production policies simultaneously. To achieve this, the firm should entrust the planning of the two policies to some co-ordinating unit such as its corporate-planning department.

\section{SUMMARY AND CONCLUSIONS}

An interdependent model of a marketing-production system is presented in this paper. The model, itself, offers a procedure for the simultaneous planning of advertising and production policies in a firm.

Besides presenting the interdependent mode1, a procedure for planning advertising and production policies in a decentralized fashion is given. The procedure is based on the assumptions that the firm's ideal organization problem is the one described by the interdependent model and that the adjusted profit margin for the marketing department is constant with respect to time. 
Computational evidence in the form of several examples is presented. In each example, the solution rendered by the interdependent approach is compared with the solution rendered by the decentralized approach. It is shown that, in general, the interdependent approach works better; however, in some situations, the decentralized approach, when co-ordinated through transfer prices, can render solutions that are fairly close to the solutions rendered by the interdependent approach. Since in many organizations it is not even feasible to plan marketing and production simultaneously, knowledge of the best ways to coordinate decentralized planning is crucial. 
FOOTNOTES

1. The ideal organization problem is (see Sweeney et. al.[22]) the problem that the organization would like to solve through its decision process.

2. It can be shown that for the above function, the unit cost of production is minimum when $P(t)=P^{*}(t)$.

3 When the Hamiltonian of a control problem is linear with respect to some control variables, and non-linear with respect to the others, the problem is said to be a partially singular control problem. In this case, the Hamiltonian is linear with respect to $A(t)$ and non-linear with respect to $P(t)$.

${ }^{4} \mathrm{q}_{\mathrm{v}}$ can be considered to be the profit margin as a percent before advertising and before quadratic production and inventory costs.

5. To remove the effect of differing, end conditions [i.e. I(T), S(T) ] from the comparison, the end conditions in the solution using the decentralized approach were constrained to be equal to the optimal end conditions found in the solution using the centralized approach. 
REFERENCES

1. Abad, P.L., "Optimal Advertising and Production Policies Using the Vidale-Wolfe Mode1," A Paper Presented At the Miami Conference of ORSA/TIMS, Miami, Florida, 1976.

2. Abad, P.L., Dynamic Optimization In a Marketing-Production System, Ph.D. Dissertation, Graduate School of Business Adninistration, University of Cincinnati, (March 1979) (290 pages) .

3. Arrow, K.J., Kunz, M., Public Investment, The Rate of Return, and Optimal Fiscal Policy, The John Hopkins Press, Baltimore, Maryland, 1971.

4. Bergstrom, G.G.K., Smith, B.E., 'Multi-Item Production Planning - An Extension of the HMMS Rules," Management Science, Vol. 16, No. 10, 1979, pp. B-614: B-629.

5. Bryson, A.E., Jr., Ho, Y.C., Applied Optimal Control, Waltham, Mass.: Ginn and Company, 1969.

6. Damon, W.W., Schranm, R., "A Simultaneous Decision Model for Production, Marketing and Finance," Management Science, Vol. 19, No. 2, 1972, pp. 161-172.

7. Galbraith, J.R., "Solving Production Smoothing Problem," Management Science, Vo1. 15, No. 12, 1969, pp. B-665: B-674.

8. Hausman, W.H., McLain, J.O., "A Note on the Bergstrom-Smith Multi-Item Production Planning Mode1," Management Science, Vo1. 17, No. 11, 1972, pp. 783-785.

9. Holt, C., Modigliani, F., Muth, J., Simon, H., Planning Production, Inventory and Work Force, Englewood Cliffs, N.J.: Prentice Ha11, 1969.

10. Hwang, C.L., Fan, L.T., Erickson, L.E., "Optimum Production Policy by the Maximum Principle," Management Science, Vol. 13, No. 9, 1967, pp. 751-755. 
11. Kleindorfer, P.R., Kriebels, C.H., Thompson, G.L., Kleindorfer, G.B., "Discrete Optimal Control of Production Plan," Management Science, Vo1. 22, No. 3, 1974, pp. 261-273.

12. Koivo, A.J., Hendrivks, C.L., "On Optimization of Sales Production and Inventory Using a Stochastic Mode1," International Journal of Systems Science, Vol. 3, (1972), pp. 407-415.

13. Koyck, L.M., Distributed Lags and Investment Analysis, Amsterdam: North Holland Publishing Co., 1954.

14. Lee, E.S., Shaikh, M.A., "Optimal Production Planning By a Gradient Technique I. First Variations," Management Science, Vol. 16, No. 1, 1969, pp. 109-117.

15. Leitch, R.A., 'Marketing Strategy and the Optimal Production Schedule," Management Science, Vo1. 21, No. 3, 1974, pp. 302-312.

16. Palda, L.S., The Measurement of Cumulative Advertising Effects, Englewood Cliffs, N.J.: Prentice-Hall, 1964.

17. Pontryagin, L.S., Boltyanskii, V.G., Gamkrelidze, R.V., Mischchenko, E.F., The Mathematical Theory of Optimal Processes, Translated by D.E. Brown, New York: The McMillan Company: 1964.

18. Sasieni, M.W., "Optimal Advertising Expenditure," Management Science, Vo1. 18, No. 4, Part II, 1971, pp. 64-72.

19. Sethi, S.P., "Optimal Control of Vidale-Wolfe Advertising Model," Operations Research, Vo1. 21, (1973), pp. 998-1013.

20. Silver, E.A., "A tutorial on Production Smoothing and Work Force Balancing," Operations Research, Vol. 15, No. 6, 1967, pp. 985-1010. 
21. Sweeney, D.J., Dornoff, R.J., Abad, P.L., "Finding an Optimal Dynamic Advertising Policy," International Journal of Systems Science, Vol. 5, No. 10, 1974, pp. 977-984.

22. Sweeney, D.J., Winkofsky, W.P., Roy, Probir, Baker, N.R., "Composition vs. Decomposition: Two Approaches to Modeling Organizational Decision Processes," Management Science, Vo1. 24, No. 14, October 1978, pp. 1491-1498.

23. Thomas, J., "Linear Progranming Models for Production-Advertising Decisions:, Management Science, Vo1. 17, No. 8, 1979, pp. B-474 : B-484. 24. , "Price Reduction Decision with Deterninistic Demand," Management Science, Vo1. 16, No. 11, 1970, pp. 747-750.

25. Thompson, R.G., Proctor, M.S., "Optimal Production, Investment, Advertising and Price Control for the Dynamic Monopoly Firm," Management Science, Vol. 16, No. 3, 1969, pp. 211-220.

26. Vidale, M.L., and Wolfe, H.B., "An Operations Research Study of Sales Response to Advertising," Operations Research, Vol. 5, (June 1957), pp. 370-381.

27. Welam, V.P., "On a Simultaneous Decision Model for Marketing, Production and Finance," Management Science, Vol. 23, No. 9, 1977, pp. 1005-1011. 
Faculty of Business

McMaster University

WORKING PAPER SERIES

101. Torrance, George W., "A Generalized Cost-effectiveness Model for the Evaluation of Health Programs," November, 1970.

102. Isbester, A. Fraser and Sandra C. Castle, "Teachers and Collective Bargaining in Ontario: A Means to What End?" November, 1971.

103. Thomas, Arthur L., "Transfer Prices of the Multinational Firm: When Will They be Arbitrary?" (Reprinted from: Abacus, Vo1. 7, No. 1, June, 1971).

104. Szendrovits, Andrew Z., "An Economic Production Quantity Model with Holding Time and Costs of Work-in-process Inventory," March, 1974.

111. Basu, S., "Investment Performance of Common Stocks in Relation to their Price-eamings Ratios: A Text of the Efficient Market Hypothesis," March, 1975.

112. Truscott, William G., "Some Dynamic Extensions of a Discrete LocationAllocation Problem," March, 1976.

113. Basu, S. and J.R. Hanna, "Accounting for Changes in the General Purchasing Power of Money: The Impact on Financial Statements of Canadian Corporations for the Period 1967-74," April, 1976. (Reprinted from Cost and Management, January-February, 1976).

114. Deal, K.R., "Verification of the Theoretical Consistency of a Differential Game in Advertising," March, 1976.

114a. Deal, K.R. "Optimizing Advertising Expenditures in a Dynamic Duopoly," March, 1976.

115. Adams, Roy J., "The Canada-United States Labour Link Under Stress," [1976].

116. Thomas, Arthur L., "The Extended Approach to Joint-Cost Allocation: Relaxation of Simplifying Assumptions," June, 1976.

117. Adams, Roy J. and C.H. Rumme1, "Worker's Participation in Management in West Germany: Impact on the Work, the Enterprise and the Trade Unions," September, 1976.

118. Szendrovits, Andrew Z., "A Comment on 'Optimal and System Myopic Policies for Multi-echelon Production/Inventory Assembly Systems'," [1976].

119. Meadows, Ian S.G., "Organic Structure and Innovation in Small Work Groups," October, 1976. 
120. Basu, S., "The Effect of Eamings Yield on Assessments of the Association Between Annual Accounting Income Numbers and Security Prices," October, 1976.

121. Agarwal, Naresh C., "Labour Supply Behaviour of Married Women - A Model with Permanent and Transitory Variables," October, 1976.

122. Meadows, Ian S.G., "Organic Structure, Satisfaction and Personality," October, 1976.

123. Banting, Peter M., "Customer Service in Industrial Marketing: A Comparative Study," October, 1976. (Reprinted from: European Journal of Marketing, Vo1. 10, No. 3, Summer, 1976).

124. Aivazian, V., "On the Comparative-Statics of Asset Demand," August, 1976.

125. Aivazian, V., "Contamination by Risk Reconsidered," October, 1976.

126. Szendrovits, Andrew Z. and George 0. Wesolowsky, "Variation in Optimizing Serial Multi-Stage Production/Inventory Systems, March 1977.

12]. Agarwal, Naresh C., "Size-Structure Relationship: A Further Elaboration," March 1977.

128. Jain, Harish C., "Minority Workers, the Structure of Labour Markets and Anti-Discrimination Legislation," March, 1977.

129. Adams, Roy J., "Employer Solidarity;" March, 1977.

130. Gould, Lawrence I. and Stanley N. Laiken, "The Effect of Income Taxation and Investment Priorities: The RRSP;" March 1977.

131. Callen, Jeffrey L., "Financial Cost Allocations: A Game-Theoretic Approach," March 1977.

132. Jain, Harish C., "Race and Sex Discrimination Legislation in North America and Britain: Some Lessons for Canada," May, 1977.

133. Hayashi, Kichiro. "Corporate Planning Practices in Japanese Multinationals." Accepted for publication in the Academy of Management Journal in 1978.

134. Jain," Harish :C., Neil-Hood and Steve Young, "Cross-Cultural Aspects of Personnel Policies..in Multi-Nationals: A Case Study of Chrysler UK", June, 1977.

135. Aivazian, V. and J. L. Callen, "Investment, Market Structure and the Cost of Capital", July, 1977. 
136. Adams, R. J., "Canadian Industrial Relations and the German Example", October, 1977.

137. Callen, J. L., "Production, Efficiency and Welfare in the U.S. Natural Gas Transmission Industry", October, 1977.

138. Richardson, A. W. and Wesolowsky, G.0., "Cost-Volume-Profit Analysis and the :Value of. Information.", November, 1977.

139. Jain, Harish C., "Labour Market Problems of Native People in Ontario", December, 1977.

140. Gordon, M.J.and L.I. Gould, "The Cost of Equity Capital: A Reconsideration", January, 1978.

141. Gordon, M.J. and L.I. Gould, "The Cost of Equity Capital with Personal Income Taxes and Flotation Costs", January 1978.

142. Adams, R. J., "Dunlop After Two Decades : Systems Theory as a Framework For Organizing the Field of Industrial Relations", January, 1978.

143. Agarwal, N.C. and Jain, H.C., "Pay Discrimination Against Women in Canada: Issues and Policies", February, 1978.

144. Jain, H. C. and Sloane, P.J., "Race, Sex and Minority Group Discrimination Leglslation in North America and Britain", March, 1978.

145. Agarwal, N.C., "A Labor Market Analysis of Executive Earnings", June, 1978.

146. Jain; H. C. and.Young, A., "Racial Discrimination" in the U.K. Labour Market : Theory and Evidence", June, 1978.

147. Yagil, J., "On Altemative Methods of Treating Risk," September 1978.

148. Jain, H. C., "Attitudes toward Communication System: A Comparison of Anglophone and Francophone Hospital Employees," September, 1978

149. Ross, R., "Marketing Through the Japanese Distribution System", November, 1978.

150. Gould, Lawrence I. and Stanley N. Laiken, "Dividends, vs. Capital Gains Under Share Redemptions," December, 1978.

151. Gould, Lawrence I. and Stanley N. Laiken, "The Impact of General Averaging on Income Realization Decisions: A Caveat on Tax Deferral," December, 1978.

152. Jain, Harish C., Jacques Normand and Rabindra N. Kanungo, "Job Motivation of Canadian Anglophone and Francophone Hospital Employees", April, 1979.

153. Stidsen, Bent, "Communications Relations", April, 1979.

154. Szendrovits, A. Z. and Drezner, Zvi, "Optimizing N-Stage Production/ Inventory Systems by Transporting Different Numbers of Equal-Sized Batches at Various Stages", April, 1979. 
155. Truscott, W. G., "Allocation Analysis of a Dynamic Distribution Problem", June, 1979 .

156. Hanna, J. R., "Measuring Capital and Income", November, 1979.

157. Deal, K. R., "Numerical Solution and Multiple Scenario Investigation of Linear Quadratic Differential Games", November, 1979.

158. Hanna, J. R., "Professional Accounting Education in Canada : Problems and Prospects", November, 1979.

159. Adams, R. J., "Towards a More Competent Labor Force : A Training Levy Scheme for Canada", December, 1979.

160. Jain, H. C., "Management of Human Resources and Productivity", February, 1980.

161. Wensley, A., "The Efficiency of Canadian Foreign Exchange Markets", February, 1980.

162. Tihanyi, E., "The Market Valuation of Deferred Taxes", March, 1980.

163. Meadows, I. S., "Quality of Working Life : Progress, Problems and Prospects", March, 1980.

164. Szendrovits, A. Z., "The Effect of Numbers of Stages on Multi-Stage Production/Inventory Models - An Empirical Study", April, 1980.

165. Laiken, S. N., "Current Action to Lower Future Taxes : General Averaging and Anțicipated Income Models", April, 1980..

166. Love, R. F., "Hull Properties in Location Problems", April, 1980.

167. Jain, H. C., "Disadvantaged Groups on the Labor Market", May, 1980.

168. Adams, R. J., "Training in Canadian Industry : Research Theory and Policy Implications", June, 1980.

169. Joyner, R. C., "Application of Process Theories to Teaching Unstructured Managerial Decision Making", August, 1980.

170. Love, R. F., "A Stopping Rule for Facilities Location Algorithms", September, 1980.

171. Abad, Prakash L., "An Optimal Control Approach to Marketing - Production Planning", October, 1980. 
Innis REF

$H B$

74.5

- R47

no. 572

1281 